\title{
TEACHERS' PERCEPTIONS ABOUT THE IMPORTANCE OF ENGLISH FOR YOUNG LEARNERS
}

\author{
Ayu Oktaviani ${ }^{1}$ \\ STKIP PGRI LUBUKLINGGAU \\ Asahi Fauzan ${ }^{2}$ \\ STKIP PGRI LUBUKLINGGAU \\ damerayu13@gmail.com ${ }^{1}$
}

Submit, 06-11-2017 Accepted,30-12-2017 Publish,30-12-2017

\begin{abstract}
The objective of the research was to find out teachers' perceptions about the importance of English for young learners at Elementary Schools in Lubuklinggau Timur I . The sample of the research was 83 teachers from 4 Elementary Schools in Lubuklinggau Timur I. The samples were taken through cluster random sampling. The researcher used survey research and the data were collected by using questionnaire and interview. Technique for analyzing the data used simple basic statistical technique. The data were scored by using Likert scale. The results of the research were 1) If the young learners learn English early, the English mastery will be better, 2) English will be useful for the young learners to get a job in the future, and 3) By mastering English, the young learners will have the social and economic benefits in the future. Therefore, it can be concluded that the teachers of Elementary Schools in Lubuklinggau Timur I agreed that English for Young Learners was important.
\end{abstract}

Keyword: teachers' perceptions, importance of English, young learners

\section{INTRODUCTION}

Today, ASEAN Economic Community has been implemented, where all ASEAN countries have to compete each other in order to be not isolated. Facing this condition, the countries have some challenges to be solved. According to Ardayati (2016:6), how the students have a good ability of speaking English is one of the challenges for the countries to face the ASEAN Economic Community.

Actually, the Indonesian government has realized that English is important for the country's development, especially in the effort of human resource development. Therefore, as a policy, the government has published Law Regulation No. 20 in 2003 about National Education System and Government Regulation No. 19 in 2005 about Standard of National Education. These policies are used as the guideline for all education components in conducting the Indonesian education system. 
Decentralization of education in Indonesia has encouraged the local governments to make their own decisions relative to some portion of curricular space in the use of some learning hours that has become known as "local content" (Musthafa 2010:1). As result of this decentralized decision-making, since last decade, public interest in English for Young Learners (EYL) has become enhanced. This is evidenced in increasing the number of district and city governments all over the country which offer English classes at the elementary school level.

The students of Elementary School include young age children who are able to learn a new language easier. According to Suyanto (2008:15), Indonesian young learners are elementary schools students between 6 to 12 years old children. They are divided into two groups, younger group (6 to 8 years old) and older group (9 to 12 years old). Whereas, based on level, they are called Lower Classes, the students of grade 1, 2 and 3 and Upper Classes, the students of grade 4, 5 and 6.

Morrow (2011:7) states that learning English in elementary schools may offer children a number of possible advantages if the instructional goals and methods are appropriate for the learners' ages. According to Brown (2007:24), there are five categories may help give some practical approaches for teaching children. They are intellectual development, attention span, sensory input, affective factors, and authentic, meaningful language. Therefore, to attain the goals of teaching and learning process, the young learners should be taught by a good teacher with the appropriate methods.

The teacher-student relationship is one of the most powerful elements within the learning environment (Liberante, 2012:1). The teachers are the second parent for their students; they know what the students' need, especially in the school environment. For example, the teachers understand what the students need in the classroom activity, included a good subject which should be learned by the students.

Many teachers of elementary school in Indonesia consider that English is important for young learners; they agree that English is useful for the future of children. According to Read (2003:4), there are some reasons for starting language learning early. These includes, the value of increased time, the possibility of better pronunciation and fluency, the possibility of greater global awareness and intercultural competence, and the value of bilingualism.

In the Elementary Schools of Lubuklinggau, English is an additional subject. English is learned as supporting subject for the students to develop their creativity, especially in language learning. According to Novtarina, Ningsih, and Anisa, the English teachers of Elementary Schools in Lubuklinggau Timur 1, English is important for young learners. They agree that there are many benefits 
for young learners to learn English early. One of the benefits is the students will have the basic of English learning that will be useful when they face English subject as compulsory subject in Junior and Senior High School.

Teachers' perception about the importance of English for young learners in elementary school is important thing for supporting the process of teaching and learning. The teachers who know that English is important for young learners will realize to teach more enthusiasm and try to be a good teacher for their students. It impacts to the increasing of teaching and learning process, finally upgrades the national education system.

Actually, the research about the importance of English for young learners has been conducted by some researchers. For example, Damar, Gursoy \& Korkmaz, (2013). The result of their research showed that EFL teacher trainers prefer language education to start at the first stage of primary school and even earlier during pre-school, which are in line with the recent changes in the curriculum.

In addition, Supriyanti (2012) conducted her research about why the children need to learn English at Elementary Schools. The result of the research showed that there were several reasons why the children need to learn English in Elementary Schools. The reasons were the widespread assumption that the children are better than adults in learning a new language, the fact that economic globalization has pushed the demand of English in the form of workforce who speak English, and the parents' enthusiasm for their children to learn English early in order to have social and economical benefits.

The emergency of this research was to know about teacher perception about English for young learner curricullum about " English is a local content." Concerning to the facts and the reasons above, the researcher was interested in doing a research entitled "Teachers' Perceptions about the Importance of English for Young Learners at Elementary Schools in Lubuklinggau Timur 1".

\section{LITERATURE REVIEW}

When the people talk about English for Young Learners (EYL), they need to understand who young learners are. Young learners are the young age students who learn English. According to Ersoz (2007:14), there are three groups of young learners based on their age and grade. First group is very young learners, they are 3-6 years old (pre-school education), second group is young learners, they are 7-9 years old $\left(1^{\text {st }}-3^{\text {rd }}\right.$ grade $)$, and the third group is older/late young learners, they are 10-12 years old $\left(4^{\text {th }}-6^{\text {th }}\right.$ grade).

In Indonesia, English young learners are the students of elementary school who learn English as additional subject or local content. According to Suyanto (2008:15), Indonesian young learners are elementary schools students between 6 
to 12 years old children. They are divided into two groups, younger group (6 to 8 years old) and older group (9 to 12 years old). Whereas, based on level, they are called Lower Classes, the students of grade 1,2 and 3 and Upper Classes, the students of grade 4, 5 and 6 .

As English becomes the world's lingua franca, countries all over the world have adopted English language as part of their education system. Many countries begin at the primary level, and students are studying the language at younger and younger ages (Jenkins, 2015:41). Indonesia is one of country that begins English subject at the primary level. Many elementary schools in Indonesia teach English as the local content. Although English is only additional subject, but it is enough to prove that English is important for Indonesian young learners.

English is very important for Indonesian students, especially for the young learners because by learning the foreign language from the early age, the language will be more easily learned. It is caused the child is in golden age learner. Lightbown \& Spada (1999:29) argued that '... childhood is the golden age for creating simultaneous bilingual children due to plasticity and virginity of the child's brain to make for superior ability specifically in acquiring the early sets or units of language'.

In addition, why English is important for young learners, it can be figured out from the theory by Supriyanti (2012:4). She stated that there are three reasons for providing English in the elementary schools.

Firstly, the widespread assumption that the younger the child learns a new language the better the result will be. Most people agree with this assumption, because the child is in golden age learner. According to Lightbown \& Spada (1999:29), the child has a superior ability in acquiring the sets or units of language, because the child is in golden age period due to plasticity and virginity of their brain.

Secondly, the fact that economic globalization has pushed the demand of English in the form of the workforce who speak English to meet the need of the international economic forces. In the business world that more globalized, many local Indonesian companies enter into the world market, and many international companies enter the local market. The use of English is becoming a necessity as the language of business. Therefore the people often find out a job vacancy in the website or newspaper, one of the criteria is able to speak English. It means that an applicant has to master English both passively and actively in order to face the international economic forces.

The last, the parents are enthusiasm for their children to learn English early in order to have social and economical benefit in the national context. The parents realize that English is very important for their children. Therefore, the parents want their children to learn English at school, teach by them self at home, 
and they also willing to spend some money for their children to learn English in the course. These efforts are done by the parents with hope their children will have social and economical benefit in the national context.

From the explanations above, it can be concluded that English is very important and very helpful and very useful for young learners in Indonesia because it has so many functions and beneficial usages in helping them to engage with global life.

The word perception leads us to such words as "observation" and "opinion," with definitions that include a view, judgment, or appraisal formed in the mind about a particular matter, a belief stronger than impression and less strong than positive knowledge, a generally held view, a formal expression of judgment or advice, and a judgment one holds as true (Bernhardt, 2007:1).

Hoffman (2008:3), suggested that a primary goal of perception is to recover, or estimate, objective properties of the physical world. It means that, the main purpose of giving perception is to appraise or presume the physical object in the environment. In order to receive information from the environment the people are equipped with sense organs, eye, ear, and nose. Each sense organ is part of a sensory system which receives sensory inputs and transmits sensory information to the brain.

\section{RESEARCH METHOD}

According to Fraenkel and Wallen (2009:390), researchers are often interested in the opinion of a large group of people about particular topic or issue. They ask a number of questions, all related to the issue, to find answer. According to Cohen, Manion, and Morrison (2005:186), surveys gather data at a particular point in time with the intention of describing the nature of existing conditions, or identifying standards against which existing conditions can be compared, or determining the relationships that exist between specific events.

The type of survey was used by the researcher was cross-sectional survey. A cross-sectional survey collects information from a sample that has been drawn from a predetermined population (Fraenkel and Wallen, 2009:391). The researcher collected the information at just one point in time, although the time it will take to collect all of the data may take anywhere from a day to a few weeks or more.

Population is the group of interest to the researcher, the group to which the researcher would like to generalize the results of the study (Fraenkel and Wallen, 2009:91). Sugiyono (2010:80) said that population is the generalization area that contain the object/subject which has certain quality and characteristic to be learned and concluded by the researcher. In this research, the population was all 
the teachers of elementary schools in Lubuklinggau Timur 1 . The total number of them was 251 from 14 elementary schools.

In this research, the researcher used cluster random sampling. According to Fraenkel and Wallen (2009:96), cluster random sampling is the selection of groups, or clusters, of subjects rather than individuals from classes already in existence. If simple random sampling is more effective with larger numbers of individuals, cluster random sampling is more effective with larger numbers of clusters.

Based on the technique of sampling above, the researcher clustered all the population or 14 schools, became 4 schools were randomly selected as the sample. The 4 schools were SD Negeri 41 Lubuklinggau, SD Negeri 42 Lubuklinggaui, SD Negeri 46 Lubuklinggau, and SD Negeri 47 Lubuklinggau, where the numbers of teachers in those schools were 83 teachers who were selected as the sample of the research.

The most common types of instruments used in survey research are the questionnaire and the interview schedule (Fraenkel \& Wallen, 2009:395). Therefore, the researcher used questionnaire and interview schedule for collecting the data from the teachers. The teachers answered the questions in the questionnaire and interview about the importance of English for young learners.

The questions in the questionnaire were formed based on the theory of Supriyanti (2012:4), about the three reasons for providing English in the elementary schools. The three of them were 1) The widespread assumption that the younger the child learn a new language the better the result will be, 2) The fact that economic globalization has pushed the demand of English in the form of the workforce who speak English to meet the need of the international economic forces, 3) The parents' enthusiasm for their children to learn English early in order to have social and economical benefit in the national context.

The questionnaire contained 18 close-ended questions on teachers' perception about the importance of English for young learners. The respondents were allowed to select the answer from the number of options or items. The researcher used Likert scale with five-level Likert item, they were 1) strongly disagree, 2) disagree, 3) neither agree nor disagree, 4) agree, and 5) strongly agree.

The second instrument for collecting the data was interview schedule. Interview schedule and questionnaire are virtually identical, but the interview schedule is administered verbally by the researcher, while questionnaire is usually self-administered by the respondent (Fraenkel \& Wallen, 2009:395). The respondents were interviewed by the researcher by using unstructured-interview. 
According to Sugiyono (2010:140), unstructured-interview is openinterview, where the researcher does not use systematically interview guideline in collecting the information. Therefore, the researcher prepared the instrument in form of 3 written questions. All interviews was started with a short introduction from the respondents, then continued to answer the questions that was given by the researcher verbally.

To analyze the research data, the researcher used descriptive analysis method by using simple basic statistical techniques. According to Latief (2012:129), the statistical techniques often used are Means (M) showing average score, Median (Med) showing the middle point in the score distribution, Modes (Mo) showing a point where most scores are obtained, Standard Deviation (SD) showing the average deviation of each score from the mean, and percentage ( $P i)$ showing proportion of the group in the population.The formula used by the researcher was percentage $(\mathrm{Pi})$. It was used to find out the proportion of the group in the population.

$$
P_{i}^{i}=\frac{F}{N} x 100 \% \quad \begin{aligned}
\text { Where }: P i & =\text { Percentage } \\
\mathrm{F} & =\text { Number of answer by respondents } \\
\mathrm{N} & =\text { Number of respondents }
\end{aligned}
$$

Fraenkel and Wallen (2009:148) explained that "In recent years, validity has been defined as referring to the appropriateness, correctness, meaningfulness, and usefulness of the specific inferences researchers make based on the data they collect". Therefore, the validity is the most important criteria to consider when preparing or selecting an instrument. The type of validity was used by the researcher was Content-validity.

Fraenkel \& Wallen (2009:154) states that "Reliability refers to the consistency of the scores obtained-how consistent they are for each individual from one administration of an instrument to another and from one set of items to another". The researcher used internal-consistency method by using split-half procedure. Internal-consistency validity is executed by doing a try-out just in once (Sugiyono, 2010:131).

\section{FINDINGS}

In this research, the findings were in the form of teachers' perceptions about the importance of English for young learners which were collected by using questionnaire and interview.

The questionnaire contained 3 indicators from Supriyanti (2012), that were 1) The widespread assumption that the younger the child learn a new language the better the result will be, 2) The fact that economic globalization has pushed the demand of English in the form of the workforce who speak English to meet the 
need of the international economic forces, 3) The parents' enthusiasm for their children to learn English early in order to have social and economical benefit in the national context.

These 3 indicators formed to be 18 expressions on teachers' perceptions about the importance of English for young learners. The respondents were allowed to select the answer from the number of options or items. The researcher used Likert scale with five-level Likert items, they were 1) strongly disagree, 2) disagree, 3) neither agree nor disagree, 4) agree, and 5) strongly agree. Then, the interview contained 3 un-structured questions related to the indicators of the instrument. All interviews was started with a short introduction from the respondents, then continued to answer the questions that was given by the researcher verbally

The Widespread Assumption that the Younger the Child Learn a New Language the Better the Result Will be

Based on the results of the first indicator, generally the respondents agreed that the children who learned foreign language earlier would get the better result. It was supported from the results of interviews to the Elementary School teachers at Lubuklinggau Timur 1 as the respondent. They said that if the children learned a foreign language early, the children would be easier to receive the material. It was different with adults who were more difficult to learn a new language.

\section{The Fact that Economic Globalization has Pushed the Demand of English in the Form of the Workforce who Speak English to Meet the Need of the International Economic Forces}

Based on the results of the second indicators, most of the respondents very agreed that economic globalization had pushed the necessity of workers who were able to speak English. It was supported by the results of the interviews with the respondents. They said that the workers needed to speak English in the purpose to compete with the international workers from other countries. Moreover, Indonesia had been facing ASEAN Community Era where the country had to be ready, especially in preparing human resources who had the competences. One of the competences might be mastered was English skill.

\section{The Parents' Enthusiasm for their Children to Learn English Early in order to Have Social and Economical Benefits in the National Context}

Based on the responses from the 83 respondents about the parents hope, by mastering English, their children will have social an economic benefits in the future, it could be seen that there were $35(42,17 \%)$ respondents who were very agree, $47(56,63 \%)$ were agree and $1(1,20 \%)$ were neither agree nor disagree, it showed that the teachers as the respondents agreed that the parents hope their 
children would have social and economical benefits in the future by mastering English.

Based on the results of the third indicator, generally the respondents agreed that the enthusiasm of the parents in supporting their children to learn English, in the purpose that the children would have the social and economic benefits in the future. It was supported by the results of interviews to the Elementary school teachers in Lubuklinggau Timur 1 as the respondents. The teachers said, nowadays the parents had begun to interest in supporting and facilitating their children to learn English in the courses. Because, the parents thought English would be useful for the future of their children.

\section{DISCUSSION}

The results of the six items in the first indicator show that the respondents agree that the children who learn foreign language early as possible will get the better result. It is supported by the interviews to the respondents. The teachers as the respondents stated that if the children learn a foreign language early, the children will be easier to receive the material. According to Lightbown \& Spada (1999:29), the child has a superior ability in acquiring the sets or units of language, because the child is in golden age period due to plasticity and virginity of their brain.

Based on the results of the instruments and the theory above, it can be concluded that English for Young Learners is important. Because the children acquire and learn English better. The children are easy to receive the English material and also have the ability to memorize well. Furthermore, by learning English early, the children will have foundation of English skill. At least, they will master the basics of English that will be useful in the next level of their education.

In addition, from the answers by the respondents toward the six items in the second indicator, it can be interpreted that the Elementary School teachers in Lubuklinggau Timur 1 very agree that economic globalization has pushed the necessity of workers who are able to speak English. It is also supported by the interviews to the respondents. The respondents said that Indonesian workers have to master the English skill in order to face the economic globalization era.

Moreover, the country is facing the ASEAN Community Era where the international workers must have the competences. One of the competences have to be mastered by the international workers is English skill. Accoding to Gilang (2013:2), the use of English as language of business has pushed the demand of the workers who can speak English. English skill for the workers will be useful in supporting the communication where many the negotiations are delayed because of the employees who can not speak English fluently. 
Based on the results of the instruments and the theory above, it can be concluded that English for Young Learners is very important with the reason English will be useful for the future of children for facing the competition in the workforce. By mastering English, the children will have the advantage in applying a job in the future. Because there are many companies especially the foreign companies has the regulation where the workers have to master English.

The last, from the answers by the respondents of the six items in the third indicator, it can be interpreted that the Elementary School teachers in Lubuklinggau Timur 1 agree that the enthusiasm of the parents in supporting their children to learn English, because the parents hope their children will have social and economic benefits in the future. It is supported by the interviews to the respondents. The teachers of Elementary schools in Lubuklinggau Timur 1 as the respondents assumed that the parents have begun to interest in supporting and facilitating their children to learn English in the courses.

English is important for the future of children. The children will have many advantages by mastering English in the next time. According to Nishida (2008:4), the reason why learning a foreign language is introduced in elementary schools is to deal with globalization. It is not only required in society but also thought of as a chance to establish our identity through communication with foreigners. Therefore, for young learners, English will have many functions and beneficial usages in helping them to engage with global life.

Based on the results of the instruments and the theory above, it can be concluded that English for Young Learners is important. The reason is the young learners will have social and economic benefits in the future by mastering English. The young learners are going to have more chance to have many friends from abroad and the young learners will be easy to apply a job and then impacts to the economic benefits for them.

From the results of 3 indicators both the answers in the questionnaire and the answers in the interviews, the resarcher can conclude that English for Young Learners is important. It can be showed from the implementaion of English teaching and learning in the Elementary Schools. According to Jenkins (2015:41), many countries begin English subject at the primary level, and students are studying the language at younger and younger ages.

Since last decade, English is started to be taught at Elementary Schools as a local content. It is taught from the third grade till the sixth grade. Eventhough English is just taught as a local content, it is enough to prove that English is needed by young learners. It means that English is important for young learners. 


\section{CONCLUSION}

From the findings of the research that have been found and discussed, the researcher can conclude that the teachers of Elementary Schools in Lubuklinggau Timur 1 agree that English for Young Learners is important. From the results of the instruments, that are the answers by respondents in the questionnaire and interview, the researcher finds out several reasons why English for Young Learners is important.

The teachers of Elementary Schools in Lubuklinggau Timur 1 assumed that English for Young Learners is important because of several reasons. The first, if the young learners learn English early, the English mastery will be better, the second, English will be useful for the young learners to get a job in the future, and the last, by mastering English, the young learners will have the social and economical benefits in the future. Therefore, the researcher concludes that the teachers of Elementary Schools in Lubuklinggau Timur 1 agree that English for Young learners is important.

\section{REFERENCES}

Ardayati (2016). Tantangan Perguruan Tinggi Menghadapi MEA. Rakyat Empat Lawang.

Bernhardt, V. L. (2007). Assessing Perceptions Using Education for the Future Questionnaires. Chico: Education for the Future Initiative press. Retrieved from http://eff.csuchico.edu/downloads/EFF_AssessQs.pdf.

Brown, H D. (2007). Principles of Language Learning and Teaching (5 ${ }^{\text {th }}$ Ed.). San Francisco: Pearson Education Inc.

Cohen, L., Manion, L \& Morrison, K. (2005). Research Method in Education ( $^{\text {th }}$ Ed.). London: Routledge Falmer.

Damar, E. A., Gursoy, E. \& Korkmaz, S. C. (2013). Teaching English to Young Learners: Through the Eyes of EFL Teacher Trainers. Uludag: Uludag University. Retrieved from http://www.uludag.edu.tr/dosyalar/egitim/akademik_kadro/\%C4\%B0ng ilizce/ozptxvey.pdf.

Ersoz, A. (2007). Teaching English to Young Learners. Ankara: EDM Publishing.

Fraenkel, J.R. \& Wallen, N.E., (2009). How to Design and Evaluate Research in Education $\left(7^{\text {th }}\right.$ Ed.). New York: McGraw-Hill Companies.

Gilang (2013). Pentingya Bahasa Inggris Dalam Dunia Kerja. Retrieved from http://haigilang96.wordpress.com.

Hoffman, D.D. (2008). The Interface Theory of Perception: Natural Selection Drives True Perception to Swift Extinction. Retrieved from http://cogsci.uci.edu/-ddhoff/interface.pdf.

Jenkins, J. (2015). Global English: A resource book for students $\left(3^{\text {rd }}\right.$ Ed). London: Routledge. 
Liberante, L. (2012). The Importance of Teachers-Students Relationship, as Explored to the Lens of the NSW Quality Teaching Model. Retrieved from

http://ro.uow.edu.au/cgi/viewcontent.cgi?article $=1008 \&$ context=jseem. Lightbown, P. M. \& Spada, N. (1999). How languages are learned. Oxford: OUP. Morrow, C. (2011). How Important is English in Elementary School?. Dubai:

UEA University. from https://www.academia.edu/1201656/How_Important_is_English_inEle mentary School?auto=download.

Musthafa, B. (2010). Teaching English to Young Learners in Indonesia: Essential Requirements. Depok: Indonesia University of Education. Retrieved from http://file.upi.edu/Direktori/JURNAL/EDUCATIONIST/Vol._IV_No._ 2-Juli_2010/07_Bachrudin_Musthafa.pdf.

Nishida, H. (2008). Elementary School English Education: The Present Condition of the Japanese Education System. Tokyo: Kairyuudou. Retrieved from https://www.kansai-u.ac.jp/fl/publication/pdf forum/5/081 nishida.pdf.

Peraturan Pemerintah tentang Standar Pendidikan Nasional. (n.d.). Retrieved May 25, 2016, from https://kemenag.go.id/file/dokumen/PP1905.pdf.

Sugiyono (2010). Metode Penelitian Kuantitatif, Kualitatif dan R\&D. Bandung: Alfabeta Bandung.

Supriyanti, N. (2012). Why do Our Chlidren Need to Learn English at Elementary Schools? A Critical Review on the Provision of English to the Indonesia Elementary Schools. Yogyakarta: Universitas Negeri Yogyakarta. Retrieved from http://eprints.umk.ac.id/340/21/PROCEEDING_TEYLIN_2.152158.pdf.

Suyanto, Kasihani K.E. (2008). English for Young Learners. Jakarta: PT Bumi Aksara.

Undang-undang tentang Sistem Pendidikan Nasional. Retrieved from http://pustakamateri.web.id/undang-undang-tentang-sistem-pendidikannasional/. 


\section{APPENDIX}

The Analysis of Teachers' Perceptions

\begin{tabular}{|c|c|c|c|c|c|c|c|c|c|c|c|}
\hline \multirow{2}{*}{ No } & \multirow{2}{*}{ Expressions } & \multicolumn{2}{|c|}{ VA/5 } & \multicolumn{2}{|c|}{$\mathrm{A} / 4$} & \multicolumn{2}{|c|}{$\mathrm{N} / 3$} & \multicolumn{2}{|c|}{ DA/2 } & \multicolumn{2}{|c|}{ VDA/1 } \\
\hline & & $\mathbf{F}$ & $\%$ & $\mathbf{f}$ & $\%$ & $\mathbf{F}$ & $\%$ & $\mathbf{f}$ & $\%$ & $\mathbf{f}$ & $\%$ \\
\hline 1 & $\begin{array}{l}\text { Every child is desirable } \\
\text { to be able to master one } \\
\text { of foreign language as } \\
\text { supporting skill for their } \\
\text { future }\end{array}$ & 53 & 63,86 & 30 & 36,14 & 0 & 0 & 0 & 0 & 0 & 0 \\
\hline 2 & $\begin{array}{l}\text { Foreign language is one } \\
\text { of subject which is } \\
\text { taught in the school }\end{array}$ & 16 & 19,28 & 65 & 78,31 & 2 & 2,41 & 0 & 0 & 0 & 0 \\
\hline 3 & $\begin{array}{l}\text { Foreign language, like } \\
\text { English is suggested to } \\
\text { be learned in the primary } \\
\text { school environment, so } \\
\text { that the students have a } \\
\text { foundation in leaning } \\
\text { that language }\end{array}$ & 18 & 21,69 & 60 & 72,29 & 5 & 6,02 & 0 & 0 & 0 & 0 \\
\hline \multirow{2}{*}{ No } & \multirow{2}{*}{ Expressions } & \multicolumn{2}{|c|}{ VA/5 } & \multicolumn{2}{|c|}{$A / 4$} & \multicolumn{2}{|c|}{$\mathbf{N} / 3$} & \multicolumn{2}{|c|}{$\mathbf{D A} / 2$} & \multicolumn{2}{|c|}{ VDA/1 } \\
\hline & & $\mathbf{F}$ & $\%$ & $\mathbf{f}$ & $\%$ & $\mathbf{F}$ & $\%$ & $\mathbf{f}$ & $\%$ & $\mathbf{f}$ & $\%$ \\
\hline 4 & $\begin{array}{l}\text { In learning a new/foreign } \\
\text { language, age is one of } \\
\text { factors that influence the } \\
\text { success }\end{array}$ & 14 & 16,87 & 49 & 59,04 & 18 & 21,69 & 2 & 2,41 & 0 & 0 \\
\hline 5 & $\begin{array}{l}\text { If a new or foreign } \\
\text { language is learnt early } \\
\text { as possible, the result } \\
\text { will be better }\end{array}$ & 19 & 22,89 & 61 & 73,50 & 3 & 3,61 & 0 & 0 & 0 & 0 \\
\hline 6 & $\begin{array}{l}\text { The children who are in } \\
\text { golden age, considered } \\
\text { better than adults in } \\
\text { learning a foreign } \\
\text { language }\end{array}$ & 35 & 42,17 & 33 & 39,76 & 15 & 18,07 & 0 & 0 & 0 & 0 \\
\hline 7 & $\begin{array}{l}\text { In globalization era, a } \\
\text { foreign language is one } \\
\text { of components needed to } \\
\text { support communication } \\
\text { with foreigner }\end{array}$ & 42 & 50,60 & 40 & 48,20 & 1 & 1,20 & 0 & 0 & 0 & 0 \\
\hline
\end{tabular}




\begin{tabular}{|c|c|c|c|c|c|c|c|c|c|c|c|}
\hline 8 & $\begin{array}{l}\text { The most commonly } \\
\text { foreign language that is } \\
\text { mastered by people } \\
\text { around the world is } \\
\text { English }\end{array}$ & 31 & 37,35 & 49 & 59,04 & 3 & 3,61 & 0 & 0 & 0 & 0 \\
\hline 9 & $\begin{array}{l}\text { One of the reasons why } \\
\text { English become a } \\
\text { language that is wanted } \\
\text { to be learnt, because } \\
\text { English is the lingua } \\
\text { franca }\end{array}$ & 44 & 53,01 & 37 & 44,58 & 2 & 2,41 & 0 & 0 & 0 & 0 \\
\hline \multirow{2}{*}{ No } & \multirow{2}{*}{ Expressions } & \multicolumn{2}{|c|}{ VA/5 } & \multicolumn{2}{|c|}{$\mathrm{A} / 4$} & \multicolumn{2}{|c|}{$\mathrm{N} / 3$} & \multicolumn{2}{|c|}{$\mathrm{DA} / 2$} & \multicolumn{2}{|c|}{ VDA/1 } \\
\hline & & $\mathbf{F}$ & $\%$ & f & $\%$ & $\mathbf{F}$ & $\%$ & $\mathbf{f}$ & $\%$ & $\mathbf{f}$ & $\%$ \\
\hline 10 & $\begin{array}{l}\text { In ASEAN Community } \\
\text { Era, the necessity of } \\
\text { English skill is increased, } \\
\text { because the workers have } \\
\text { to master English }\end{array}$ & 20 & 24,10 & 59 & 71,08 & 4 & 4,82 & 0 & 0 & 0 & 0 \\
\hline 11 & $\begin{array}{l}\text { In the economic } \\
\text { globalization era, } \\
\text { workers are needed to be } \\
\text { able to speak English in } \\
\text { order to compete in the } \\
\text { international scope }\end{array}$ & 49 & 59,04 & 30 & 36,14 & 4 & 4,82 & 0 & 0 & 0 & 0 \\
\hline 12 & $\begin{array}{l}\text { Modern workers who are } \\
\text { able to master English } \\
\text { have many advantages }\end{array}$ & 49 & 59,04 & 34 & 40,96 & 0 & 0 & 0 & 0 & 0 & 0 \\
\hline 13 & $\begin{array}{l}\text { The ability of mastering } \\
\text { English by the children } \\
\text { cannot separated from } \\
\text { the parents' role who } \\
\text { guide and facilitate their } \\
\text { children to learn English }\end{array}$ & 26 & 31,33 & 56 & 67,47 & 1 & 1,20 & 0 & 0 & 0 & 0 \\
\hline \multirow{2}{*}{ No } & \multirow{2}{*}{ Expressions } & \multicolumn{2}{|c|}{ VA/5 } & \multicolumn{2}{|c|}{$\mathrm{A} / 4$} & \multicolumn{2}{|c|}{$\mathrm{N} / 3$} & \multicolumn{2}{|c|}{ DA/2 } & \multicolumn{2}{|c|}{ VDA/1 } \\
\hline & & $\mathbf{F}$ & $\%$ & f & $\%$ & $\mathbf{F}$ & $\%$ & $\mathbf{f}$ & $\%$ & $\mathbf{f}$ & $\%$ \\
\hline 14 & $\begin{array}{l}\text { Most Indonesian parents } \\
\text { very support their } \\
\text { children to learn English } \\
\text { early, because English is } \\
\text { useful for the children's } \\
\text { future }\end{array}$ & 40 & 48,19 & 39 & 46,99 & 4 & 4,82 & 0 & 0 & 0 & 0 \\
\hline 15 & $\begin{array}{l}\text { The parents very support } \\
\text { the process of English } \\
\text { teaching and learning } \\
\text { activity in the }\end{array}$ & 25 & 30,12 & 56 & 67,47 & 2 & 2,41 & 0 & 0 & 0 & 0 \\
\hline
\end{tabular}




\begin{tabular}{|c|c|c|c|c|c|c|c|c|c|c|c|}
\hline & $\begin{array}{l}\text { Elementary School, that } \\
\text { the children can } \\
\text { recognize the basics of } \\
\text { English }\end{array}$ & & & & & & & & & & \\
\hline 16 & $\begin{array}{l}\text { Most parents are willing } \\
\text { to spend their money for } \\
\text { their children to learn } \\
\text { English in the course in } \\
\text { order to support the } \\
\text { children's ability in } \\
\text { mastering English }\end{array}$ & 42 & 50,60 & 33 & 39,76 & 8 & 9,64 & 0 & 0 & 0 & 0 \\
\hline 17 & $\begin{array}{l}\text { All efforts by the parents } \\
\text { above, are the form of } \\
\text { the parents' enthusiasm } \\
\text { in supporting their } \\
\text { children to be able to } \\
\text { master English }\end{array}$ & 26 & 31,32 & 53 & 63,86 & 4 & 4,82 & 0 & 0 & 0 & 0 \\
\hline \multirow{2}{*}{ No } & \multirow{2}{*}{ Expressions } & \multicolumn{2}{|c|}{ VA/5 } & \multicolumn{2}{|c|}{ A/4 } & \multicolumn{2}{|c|}{$\mathbf{N} / 3$} & \multicolumn{2}{|c|}{ DA/2 } & \multicolumn{2}{|c|}{ VDA/1 } \\
\hline & & $\mathbf{F}$ & $\%$ & f & $\%$ & $\mathbf{F}$ & $\%$ & f & $\%$ & $\mathbf{f}$ & $\%$ \\
\hline 18 & $\begin{array}{l}\text { The parents hope, by } \\
\text { mastering English, their } \\
\text { children will have social } \\
\text { an economic benefits in } \\
\text { the future }\end{array}$ & 35 & 42,17 & 47 & 56,63 & 1 & 1,20 & 0 & 0 & 0 & 0 \\
\hline
\end{tabular}

